\title{
A MEDICO-LEGAL REPORT OF THE SIXTEENTH CENTURY FROM MALTA
}

\author{
by
}

\author{
PAUL CASSAR*
}

\section{THE MANUSCRIPT}

Among the manuscripts bearing mainly on Maltese ecclesiastical affairs, preserved in the archives of the Cathedral at Mdina, one occasionally comes across documents containing material of interest to the medical historian. One such manuscript of the mid-sixteenth century deals with the procedure for the annulment of marriage on medical grounds.

The manuscript consists of four folios showing two different types of handwriting. The calligraphy recording the deposition of the medical experts, Dr. Joseph Callus and Dr. Rainerio de Bonellis, is in a curial hand, while that registering the submissions of plaintiff and defendant is modern, with marginal notes in curial script. The report of the two doctors is written in Latin, often in an abbreviated form; the testimony of the two parties in the suit is partly in Latin and partly in old Italian.

The folios measure $32 \mathrm{~cm}$. $\times 22 \mathrm{~cm}$. and bear a watermark of an open hand surmounted by a star-shaped flower with five petals. ${ }^{1}$

\section{MEDICAL REPORT}

On 7 July (15th indiction) 1542, Mathia, the legitimate and natural daughter of Dionysius Busuttil and his wife Catherine, brought an action for the annulment of her marriage with John Azzopardi in the Bishop's Curia at Notabile (Mdina). She also sought a declaration that she was free to contract lawful matrimony with someone else. The court undertook to hear the case on condition that the plaintiff (a) agreed to abide by its decision; (b) bound herself not to marry while proceedings were in progress; and (c) submitted a guarantee of twenty "ounces"- to be forfeited in favour of the Bishop's Table if she failed to honour the decision of the ecclesiastical tribunal. ${ }^{2}$ This last measure was necessary as the Bishop's Court had no powers to ensure the enforcement of its decisions.

She based her petition on the fact that she had married John against her own will; in fact, she pleaded, the marriage had been arranged by her father and her fatherin-law and she had expressed her dissent both "tacitly and openly". Her husband, however, refuted this argument and declared on oath that Mathia had not objected to have him as her spouse but had, after the wedding, lived and shared with him the same "roof, bed and board" for two months.

But Mathia brought forward another cause for considering the marriage to be null and void. She rebutted that she could not be compelled to live with John because of

*St. Luke, Pope Alexander VII Junction, Balzan, Malta. 
an impediment consisting of a "natural infirmity" on his part. She alleged that he suffered from a defect in the configuration of his "virile member" on account of which he did not "urinate in a natural way like other men"; in fact, the aperture from which urine and sperm are expelled was placed on the inferior aspect and behind the head of his member.

The Bishop's Court nominated two medical experts, Magnificus Joseph Callus "doctor of art and medicine" and the noble Rainerio de Bonellis (Bonello) "physician and surgeon and professor of medicine", to examine John and draw up a report on their findings. The two experts examined John in the presence of the Vicar General and his Curia and on 21 July Dr. Callus presented to the court the results of their investigation. He stated that John's male member was "inept or incapable and also useless for deflorating or perforating" because it was short and curved, this curvature tending, in the judgment of Dr. Callus, to become more pronounced with turgidity of the penis which, consequently, showed no erection. The meatus was on its inferior aspect at the root of the prepuce, which had a narrow opening. Because of these defects John's member could not project the sperm "like an arrow in nature's field" (sicut sagitta in campum naturae) and was, therefore, incapable of "generating and begetting children". Dr. Callus strengthened his conclusion by referring to the views of "eminent and illustrious doctors of medicine" especially Galen, Rhazes, Avenzoar and Avicenna. Dr. R de Bonellis agreed with Dr. Callus.

The court, on hearing the submissions of Mathia and the deposition of the two experts, ruled that the marriage between Mathia and John was null and void and that, even if it were conceded that it was binding, it could not be carried into effect and that Mathia could not be compelled to cohabit with John because of his natural defect which hindered the execution of the conjugal and procreative act. Consequently Mathia should be declared free to enter into lawful matrimony with someone else.

The court gave John a period of twelve days within which to defend himself or to challenge Mathia's petition or to make other submissions. The manuscript comes to an end at this stage of the proceedings.

\section{COMMENT}

As there is no further documentation on the case we do not know the final outcome of Mathia's action. One would imagine, however, that the medical evidence against John was so convincing that he could not contest it.

It is easy to recognize in Callus's description of John's genitalia an instance of hypospadia glandis. This is a defective development of the lower wall of the male urethra on account of which its orifice opens along the undersurface of the penis and is thus directed downwards instead of forwards. Besides, the organ is usually small and stunted and the glans is bent over the urethral orifice. When these defects are marked they interfere with effective sexual intercourse owing to the impossibility of penetration of the vagina and the deposition of semen therein. In this respect one cannot help remarking on the very apt comparison drawn by Dr. Callus between the force with which the semen is ejected by the erect penis and the striking power of an arrow shot from a bow. 


\section{Texts and Documents}

Callus's report shows that he was well acquainted with the anatomical and functional features of hypospadia glandis and that he had a firm grasp of the issue which involved both impotentia coeundi and impotentia generandi. Indeed his deposition contains no statement which would not be incorporated in a report on this pathological condition today, for his observations still accord with the trends of current medical jurisprudence.

It is pertinent to the consideration of this document to outline the state of forensic medicine in Europe and of the matrimonial laws in Malta in the fourth decade of the sixteenth century.

The status and function of the medical expert in connexion with legal procedures were first clearly recognized by the Justinian Laws which appeared between A.D. 529 and 564 and which regarded the function of the medical expert to be that of assisting the judiciary by his impartial interpretation and opinion based on his specialized knowledge.

No further progress was registered in forensic medicine in the thousand years that followed the fall of Rome until 1553, when the Caroline Code was proclaimed by Emperor Charles $V$ as the code of law to be observed throughout his Empire. Here it was definitely laid down that expert medical testimony had to be obtained for the guidance of the judges in cases involving the person. However, the body of medical knowledge and experience that had accumulated through the ages in relation to jurisprudence remained fragmentary and was scattered in the writings of various medical authors until it was gathered and integrated into an organized discipline in 1602 by Fortunato Fedele (1550-1630) and, between 1621 and 1635, by Paolo Zacchia (1584-1659). ${ }^{3,4}$

Callus's report of 1542 , therefore, antedates the Caroline Code by eleven years and the pioneer treatises of Fedele and of Zacchia by more than half a century: hence the reason why the authors he cites in support of his thesis are Galen (c. A.D. 131-200) and the exponents of Arabian medicine, Rhazes (860-932), Avicenna (980-1037) and Avenzoar (1072-1162).

In spite of the passage of many centuries, these writers were still accepted as the most authoritative medical sources in Callus's days. Islamic physicians had preserved the medical literature of ancient Greece through Arabic translations which were in turn rendered into Latin and the vernacular. Translations of Galen, Rhazes and Avicenna were printed after $1469^{5}$ and continued to figure in the programme of studies in the universities of the West for many years after Callus's time.

When referring to the writings of Galen and the Arab physicians, Callus quotes only the Liber, Capitulum and Tractatio but omits to specify the titles and other bibliographical data of the works he cites. I have succeeded in tracing only one of his references, that to Avicenna, in an edition of $1564 .^{\circ}$ Attempts to identify the works of the other authors and to check Callus's references to them have proved fruitless.?

\section{CANON LAW}

Canon law is a body of ecclesiastical enactments regulating the constitution of the Christian church and the discipline of its priests and lay subjects. Most of these laws were evolved during the period extending from the twelfth to the sixteenth 


\section{Texts and Documents}

centuries. Marriage is one of the matters dealt with. Since Malta became a Christian country in Roman times (A.D. 60), the state has acknowledged Canon Law as the only legal code regulating the contract and the annulment of marriage and the Bishop's Curia as the only competent tribunal to take cognizance of cases where the validity of marriage is in question. ${ }^{8}$

Canon Law recognizes impotence as a "bodily defect" justifying the annulment of marriage and lays down that where this question arises the "bodies are to be inspected by a surgeon, in the case of a man, and by an honest and trustworthy midwife, in the case of a woman". 9

The Bishop's Curia in Malta was even more cautious than these injunctions in determining the existence of bodily defects causing impotence, for instead of a mere surgeon it appointed two physicians, one of whom was also a surgeon. Criticism may be levelled at the court procedure of having the medical examination carried out in the presence of the court officials as being both unscientific and ethically repugnant. We must remember, however, that these methods, regarded by twentieth-century medical men as constituting a serious failing of the legal system, were quite within the accepted framework of sixteenth-century forensic practice. Indeed a far more objectionable procedure for proof of impotence was insisted upon by some European law courts since at least the fourteenth century. This was the so-called congrès which consisted in inducing the man and woman to have sexual intercourse in the presence of a matrone savante et expérimentée who afterwards reported to the medico-legal expert. ${ }^{10}$ This "proof", was still required by some lay courts in Germany as late as the eighteenth century. ${ }^{11}$

\section{THE MEDICAL EXPERTS}

About Dr. Rainerio de Bonellis (Bonello) it has not been possible to retrieve much information beyond the fact that he had to appeal to the Court officials to induce his patients to pay the fees due to him in 1529 and that he drew up his will on 7 July $1550 . .^{12} \mathrm{He}$ was dead by $1556 .^{13}$

In the sixteenth century the dichotomy between the "art" of medicine and the "craft" of surgery was still prevalent so that these two branches of the healing art were usually exercised by different practitioners with contrasting educational backgrounds. Dr. de Bonellis, however, was qualified to practise both, so he must have combined a formal training in medicine with practical experience in anatomy and surgery.

Slightly more is known about Dr. Callus. In fact there is some confusion surrounding his identity. In folk memory he is known as Matthew Callus, but documentary evidence shows that his real name was Joseph and leaves no doubt that he was a physician. There was a Matthew Callus from Rabat, but he flourished in the last quarter of the fifteenth century (1488) and was already dead by $1532 .{ }^{14}$ As the biography of Joseph Callus has been dealt with elsewhere, ${ }^{15}$ only the chief facts of his life will be touched upon. He was the son of the pharmacist Hyeronimus. ${ }^{13}$ being born probably between 1500 and 1510 . He had two brothers, Antonio, a pharmacist, and James to whom he bequeathed his property by his testament dated 19 August 1548. ${ }^{16} \mathrm{He}$ may have pursued his medical studies on the Italian mainland and by 


\section{Texts and Documents}

1530 was practising in Sicily. At this juncture the Order of the Knights of St. John of Jerusalem was preparing to leave Sicily to take possession of Malta and Callus joined its navy as a physician. About 1537 he was appointed physician of Mdina, ${ }^{17}$ then the capital city of the island. Not all his talents, however, were devoted to medicine and he made a name as a major public figure in Maltese politics. In 1560 a number of citizens, in protest against the usurpation of their rights by the Order of St. John, drew up a secret petition addressed to Philip II, King of Spain, to intercede with the Grand Master of the Order of St. John and to induce him to respect their rights and privileges. Dr. Callus was alleged to have been the author of this petition which fell into the hands of the Grand Master. Callus was accused of treason, tried and hanged in 1561.

A perusal of Callus's medico-legal report reveals two new facets of his professional life: (a) his academic education was based on the medical literature of Arabian authors as was the case with most of his contemporaries in Europe; and (b) apart from being a practising physician he was also acknowledged as a medico-legal expert, from which we may deduce that he was a practitioner of established repute by 1542 . In fact no less a personage than Grand Master Jean de La Valette referred to him as eruditissimus vir. ${ }^{18}$

\section{IMPORTANCE OF THE DOCUMENT}

This manuscript is of singular importance because it is the earliest medico-legal report so far discovered in Malta. Until its discovery we knew, nothing about the education and medical training of doctors practising in Malta in the early sixteenth century. The allusions to medieval Arabian authors provide us, for the first time, with evidence of the influence of Arabian medicine. It adds to the list of early medical practitioners in Malta by recording the presence in the island of a physician and surgeon, Dr. R. de Bonellis, whose existence was hitherto unkown. Apart from its medical interest, it records the first known action for annulment of marriage before the Bishop's Court in Malta.

\section{ACKNOWLEDGEMENTS}

I am greatly indebted to the Very Rev. Mgr. Joseph Borg, the Rev. Fr. P. M. Fsadni O.P. and Professor Adalberto Pazzini, of the Institute of the History of Medicine of the University of Rome for their help in the preparation of this paper.

\section{REFERENCES}

1. Cathedral Archives, Mdina, C.E.M. 22, Acta originalia 1542, fo. 34-37t.

2. Cathedral Archives, Mdina, Reg. Act. 1541-46, fo. 76t.

3. A. Pazzini, Saggi critici di storia della medicina, Rome, 1959, p. 128.

4. S. Smith, 'The history and development of forensic medicine, Br. med. J., 1951, i: 599.

5. L. Colapinto, 'Dall' alchimia alla moderna tecnologia farmaceutica', Pag. Stor. Med., 1973, 17: 66.

6. Avicennae libri in re medica omnes, Venice, 1564, vol. 1, p. 912.

7. A. Pazzini, personal communication, 1973.

8. P. de Bono, Sommario della storia della legislazione in Malta, Malta, 1897, pp. 64-74.

9. J. Devoti, Institutionum canonicarum, Bassani, 1834, p. 132. 


\section{Texts and Documents}

10. L. Derobert, Histoire de la médecine légale, Zacchia, 1973, vol. 9, series 3a, p. 1.

11. G. Maschka, Trattato di medicina legale, Naples, 1891, p. 10.

12. Royal Malta Library, Valletta. Libr. AD 40, fo. 491.

13. Cathedral Archives, Mdina, MS. 280, fo. 100.

14. Royal Malta Library, Valletta. Libr. AD 50a, fo. 255, 276, 283.

15. P. Cassar, Medical history of Malta, London, Wellcome Historical Medical Library, 1965 , p. 17.

16. Royal Malta Library, Valletta. Libr. AD 50b, fo. 253-254.

17. Royal Malta Library, Valleta. Univ. 13, fo. 127 t.

18. Royal Malta Library, Valletta. Archives 427, fo. 257 t. 